\title{
Flowering attributes of Henckelia Royal Queen influenced by pinching and Paclobutrazol application
}

\author{
N. P. C. H. Wickramasinghe ${ }^{1}$, T. H. Seran ${ }^{1 *}$ and M. M. D. J. Senarathne ${ }^{2}$ \\ ${ }^{I}$ Department of Crop Science, Faculty of Agriculture, Eastern University, Chenkalady, Sri Lanka \\ ${ }^{2}$ Research and Floriculture Unit, Royal Botanical Garden, Peradeniya, Sri Lanka
}

Received: 21 March 2021

Revised: 11 April 2021

Accepted: 28 June 2021

DOI: https://doi.org/10.3329/bjsir.v56i3.55965

\begin{abstract}
An experiment was carried out to determine the effect of pinching practice and different concentrations of Paclobutrazol (PBZ) on the flowering of Henckelia Royal Queen plants.Completely randomized design with eight treatment combinations of pinching or non-pinching and different concentrations of Paclobutrazol $(0,15,30$ and $60 \mathrm{ppm})$ soil drenchwas usedwith eight replicates for each treatment. Pinching was practiced twice at two weeks intervals. Flowering parameters viz. number of flower buds, days taken to flowering, number of flowers, pedicel length, corolla length and corolla width were measured at two weeks intervals from $9^{\text {th }}$ week after the treatment application. Results disclosed that plants showed better flowering performances $(\mathrm{P}<0.05)$ with increasing concentrations of $\mathrm{PBZ}$, but degree of leaf deformation was increased. Therefore, the application of $15 \mathrm{ppm}$ PBZ with pinching showed better to obtain dwarf Henckelia Royal Queen plants with improved flowering quality as commercial potted plants.
\end{abstract}

Keywords: Flowering; Henckelia; Paclobutrazol; Pinching; Soil drench

\section{Introduction}

Gesneriaceae is a flowering plant family which comprisesof large and colorful plants. The Genus Henckelia comes under family Gesneriaceae and its species previously grouped under Didymocarpus sect, Orthoboea and in the genus Chirita (Weber et al., 2011). Parental materials of Henckelia Royal Queen(Hybrid of Henckelia mooni and Henckelia angusta) are classified under genus Henckelia (Weber, 2004). Henckelia Royal Queen is found in Royal Botanical Garden, Peradeniya, Sri Lanka andmorphologically most similar to Henckelia mooni plant. Henckelia Royal Queen is terrestrial; perennial herb and often shows highly creeping attributes. This creeping nature decreases the potential of Henckelia species to introduce to the floriculture market. Generally, this plant is vegetatively propagated through stem cuttings and sexually reproduced through seeds.
Plant growth regulators are highly used in floriculture industry for root initiation, promoting stem growth and also for stimulating flowering and fruiting. Paclobutrazol is one of the widely used plant growth retardants in potted ornamental plant industry to obtain dwarf plants. Paclobutrazol interfere with gibberellin biosynthesis by arresting the oxidation of entkaurene to ent-kauronoic acid through inactivating cytochrome P450-dependent oxygenase (Zhu et al., 2004; Rady and Gaballah, 2012) that resulted inhibited cell elongation. Further, Paclobutrazol shows fungicidal activity due to its activity as a triazole to inhibit sterol biosynthesis (Rathfon, 2005). Paclobutrazol $35 \mathrm{mg} / \mathrm{AI}$ per pot proves to reduce the plant foliage height and flower stem length, while not changing inflorescence length and delaying the flowering and fruiting of potted Thai Tulip (Pinto et al., 2006). 
In literature survey, pinching practice performs along with PBZ application in potted ornamental plant industry. Pinching defined as "removal of plant terminal growing portion of the stem due to apical dominance" (Ona et al., 2015). The shoot height, shoot diameter and number of flowers increase with the number of pruning (Brum et al., 2007) and increases the days to flowering begins but increases the number of flowers at once (Singh, 2019). Pinching is an important in controlling the flowering time and flower quality. Growth and flowering of crops can be regulated by pinching that increase quality, increase time taken to flowering. Application of pinching practices on Chrysanthemum plant showed maximum duration of flowering span, increased length of flower stalk, increased vase life, shelf life and in situ longevity of flowers (Jindal et al., 2018). Furthermore, the effect of pinching practice and Paclobutrazol application on flowering characters of Genus Henckelia has not been investigated yet. Therefore, the main objective of this experiment was to enhance quality flowering, and to investigate the results of potted Henckelia Royal Queen plants through pinching practice and Paclobutrazol soil drench application.

\section{Materials and methods}

This experiment was carried out at the 50\% shade house, Royal Botanical Garden, Peradeniya, Sri Lanka in 2020. The softwood cuttings of Henckelia Royal Queen were collected from parent plant stock, Royal Botanical Garden, Peradeniya. Potting medium was a mixture of sand and compost at 1:1 ratio (Hematharshini and Seran, 2019) which was sterilized by autoclaving and filled the pots $(9.0 \mathrm{~cm}$ height and $11.0 \mathrm{~cm}$ diameter) by leaving $1.0 \mathrm{~cm}$ from the top of pots. At the time of planting, the cuttings were treated with IBA (Indole Butyric Acid) and planted to the depth of 2.0-3.0 $\mathrm{cm}$ in the center of the pots and placed inside the plant propagators to accelerate the rooting of cuttings. The developed plants were first pinched at 18 weeks after planting according to the treatments (Table I). Thereafter, pinching was carried out two times with two weeks interval.
Paclobutrazol (PBZ) application (single dosage application) was carried out at the 18 weeks after planting but 4 days after first pinching.

The commercial product of Paclobutrazol powder (25\% WP) contains $25 \mathrm{~g}$ of active ingredient in $100 \mathrm{~g}$ of the powder. According to the treatments, required amount of PBZ powder was mixed separately with $1 \mathrm{~L}$ of water and applied to the plants as soil drench application $(30 \mathrm{ml}$ per plant) while for 0 ppm concentration, distilled water was sprayed at morning hour. Other management practices were followed uniformly.

Number of days taken to first flowering (blooming) was calculated from the day of treatment application in each and every treatment separately. Total number of flower buds, total number of flowers, the flower stalk/ pedicel length, corolla width $(\mathrm{cm})$ and corolla length $(\mathrm{cm})$ in each replication in all treatments was counted at $9^{\text {th }}, 11^{\text {th }}$ and $13^{\text {th }}$ weeks after the treatment application. Fresh and dry weights of flowers were measured by electric balance at 13 weeks after the treatment application. Dry weight of the plants was taken after oven drying the plants for overnight at $105^{\circ} \mathrm{C}$. The data obtained from the experiments were subjected to analysis of variance (ANOVA) using SAS 9.1.3 version. The treatment means were compared using Tukey's Honestly Significant Difference Test at 5\% significant level.

\section{Results and discussion}

\section{Number of days taken to first flowering}

Table II shows the days taken to first flowering of Henckelia Royal Queen plants after application of treatments (18 weeks after planting of the stem cuttings). Pinching alone has not shown the significant difference $(\mathrm{P}=0.9386)$ on number of days taken to first flowering. This result was agreed with Singh et al., (2015) who stated pinching has failed to effect on days taken to first flowering in African marigold (Tagettes

\section{Table I. Treatments used in this study}

\begin{tabular}{lcccc}
\hline Treatments & \multicolumn{3}{l}{ Paclobutrazol concentration (ppm) } \\
\hline & $0 \mathrm{ppm}$ & $15 \mathrm{ppm}$ & $30 \mathrm{ppm}$ & $60 \mathrm{ppm}$ \\
Non-pinching (P1) & $\mathrm{P} 1 \mathrm{C} 1$ & $\mathrm{P} 1 \mathrm{C} 2$ & $\mathrm{P} 1 \mathrm{C} 3$ & $\mathrm{P} 1 \mathrm{C} 4$ \\
Pinching (P2) & $\mathrm{P} 2 \mathrm{C} 1$ & $\mathrm{P} 2 \mathrm{C} 2$ & $\mathrm{P} 2 \mathrm{C} 3$ & $\mathrm{P} 2 \mathrm{C} 4$ \\
\hline
\end{tabular}


Table II. Number of days taken to first flowering and number of flowers per plant of Henckelia Royal Queen as influenced by pinching and Paclobutrazol

\begin{tabular}{|c|c|c|c|c|c|}
\hline \multicolumn{2}{|c|}{ Treatment } & \multirow{3}{*}{$\begin{array}{c}\text { Number of } \\
\text { days taken to } \\
\text { first } \\
\text { flowering }\end{array}$} & \multirow{2}{*}{\multicolumn{3}{|c|}{ Number of flowers per plant }} \\
\hline \multirow{2}{*}{$\begin{array}{l}\text { Pinching } \\
\text { practice }\end{array}$} & \multirow{2}{*}{$\begin{array}{l}\text { *PBZ solution } \\
\text { (ppm) }\end{array}$} & & & & \\
\hline & & & $9^{\text {th }}$ week & $11^{\text {th }}$ week & $13^{\text {th }}$ week \\
\hline \multirow{4}{*}{$\begin{array}{c}\text { Non- } \\
\text { pinching }\end{array}$} & 0 & $63.25 \pm 2.95$ & $1.38 \pm 0.32$ & $0.88 \pm 0.23$ & $1.63 \pm 0.26$ \\
\hline & 15 & $60.88 \pm 3.07$ & $1.00 \pm 0.38$ & $1.63 \pm 0.38$ & $2.00 \pm 0.33$ \\
\hline & 30 & $59.75 \pm 2.19$ & $1.75 \pm 0.25$ & $1.88 \pm 0.35$ & $2.63 \pm 0.26$ \\
\hline & 60 & $57.50 \pm 1.87$ & $0.75 \pm 0.25$ & $2.50 \pm 0.33$ & $2.88 \pm 0.91$ \\
\hline \multirow[t]{4}{*}{ Pinching } & 0 & $63.25 \pm 6.86$ & $1.13 \pm 0.30$ & $1.75 \pm 0.31$ & $1.88 \pm 0.23$ \\
\hline & 15 & $60.13 \pm 3.04$ & $1.75 \pm 0.41$ & $2.25 \pm 0.25$ & $2.75 \pm 0.31$ \\
\hline & 30 & $59.75 \pm 2.47$ & $1.38 \pm 0.32$ & $2.13 \pm 0.30$ & $2.63 \pm 0.50$ \\
\hline & 60 & $59.75 \pm 2.24$ & $1.38 \pm 0.32$ & $1.88 \pm 0.50$ & $2.88 \pm 0.55$ \\
\hline \multirow[t]{3}{*}{$P$ value } & Pinching & 0.9386 & 0.4164 & 0.2406 & 0.4568 \\
\hline & PBZ solution & 0.0669 & 0.4756 & 0.0637 & 0.1114 \\
\hline & $\begin{array}{l}\text { Pinching*PBZ } \\
\text { solution }\end{array}$ & 0.0267 & 0.1965 & 0.1374 & 0.8391 \\
\hline
\end{tabular}

Table III. Number of flower buds per plant of Henckelia Royal Queen at different weeks as influenced by pinching and Paclobutrazol

\begin{tabular}{|c|c|c|c|c|}
\hline \multicolumn{2}{|c|}{ Treatment } & \multirow{2}{*}{\multicolumn{3}{|c|}{ Average number of flower buds per plant }} \\
\hline \multirow{2}{*}{$\begin{array}{l}\text { Pinching } \\
\text { practice }\end{array}$} & \multirow{2}{*}{$\begin{array}{c}\text { *PBZ solution } \\
(\mathrm{ppm})\end{array}$} & & & \\
\hline & & $9^{\text {th }}$ week & $11^{\text {th }}$ week & $13^{\text {th }}$ week \\
\hline \multirow{4}{*}{ Non-pinching } & 0 & $4.25 \pm 1.29$ & $2.75 \pm 1.05$ & $2.63 \pm 1.13$ \\
\hline & 15 & $6.50 \pm 1.52$ & $11.38 \pm 2.48$ & $13.38 \pm 2.32$ \\
\hline & 30 & $7.38 \pm 1.75$ & $9.88 \pm 2.02$ & $15.63 \pm 2.56$ \\
\hline & 60 & $7.00 \pm 2.43$ & $7.38 \pm 2.28$ & $10.50 \pm 2.06$ \\
\hline \multirow{4}{*}{ Pinching } & 0 & $4.13 \pm 1.43$ & $6.25 \pm 1.68$ & $3.63 \pm 1.29$ \\
\hline & 15 & $10.88 \pm 2.29$ & $11.38 \pm 1.78$ & $12.38 \pm 2.55$ \\
\hline & 30 & $3.38 \pm 1.19$ & $6.88 \pm 1.51$ & $10.50 \pm 1.88$ \\
\hline & 60 & $2.88 \pm 0.88$ & $4.50 \pm 0.98$ & $6.88 \pm 1.46$ \\
\hline \multirow{3}{*}{$P$ value } & \multirow{3}{*}{$\begin{array}{l}\text { Pinching } \\
\text { PBZ solution } \\
\text { Pinching*PBZ } \\
\text { solution }\end{array}$} & 0.417 & 0.6414 & 0.1234 \\
\hline & & 0.0473 & 0.0019 & $<0.0001$ \\
\hline & & 0.0442 & 0.2361 & 0.4234 \\
\hline
\end{tabular}

PBZ: Paclobutrazol powder (25\% WP)

Values represent mean \pm standard error of eight replicates 
erecta). PBZ has not shown significant difference $(\mathrm{P}=0.0669)$ on number of days taken to flowering according to the data analyzed (Table II). But Abd El-aal and Mohamed (2017) stated that increasing PBZ has increased the numbers of days from planting to start flowering in Tabernaemontana coronaria Stapf plant when compared with 0 ppm PBZ treated plants. The obtained results are not in conformity with Wei and Han (1997) and Yewale et al., (1998) on Chrysanthemum grandiflora who reported that paclobutrazol at the increasing rate progressively, delayed flowering as the concentration was increased. Moreover Shahin et al., (2006) on Rudbeckia hirta and El-Bably (2008) on Anisacanthus wrightii found similar results which are disagreed with the present results.

\section{Number of flower buds}

The data presented in Table III revealed that number of buds per plant has not shown the significant difference $(\mathrm{P}>0.05)$ with pinching. Interaction also, was not shown the significant difference with number of flower buds per plant except $9^{\text {th }}$ WAT $(\mathrm{P}=0.0442)$ that shown significant with number of flower buds per plant. Nain et al. (2017) stated that the number of buds per plant increased significantly with pinching at 5\% level of significance and might be due to the reason that extra energy diverted into the production of more reproductive parts instead of vegetative parts. But present results were not agreed with that statement. Seran and Krishanthy (2009) reported that decapitation at an early vegetative growth period effectively increases the number of branches for flower production.

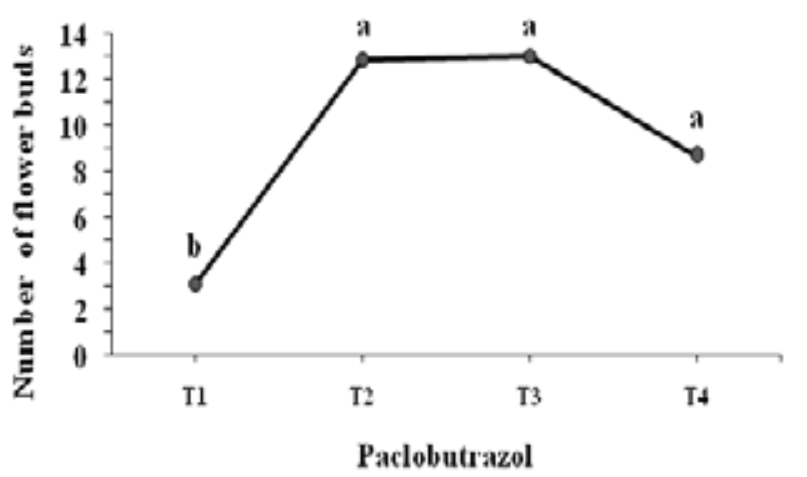

Fig. 1. Influence of Paclobutrazol powder on overall number of flower buds per plant of Henckelia Royal Queen plant at $13^{\text {th }}$ week after treatment

Table IV. Length of flower pedicel as well as length and width of corolla of Henckelia Royal Queen plant at $13^{\text {th }}$ week after treatment as influenced by pinching and Paclobutrazol

\begin{tabular}{|c|c|c|c|c|}
\hline \multicolumn{2}{|c|}{ Treatment } & \multirow{2}{*}{$\begin{array}{l}\text { Flower pedicel } \\
\text { length }(\mathrm{cm})\end{array}$} & \multirow{2}{*}{$\begin{array}{l}\text { Corolla length } \\
\qquad(\mathrm{cm})\end{array}$} & \multirow{2}{*}{$\begin{array}{l}\text { Corolla width } \\
\qquad(\mathrm{cm})\end{array}$} \\
\hline $\begin{array}{l}\text { Pinching } \\
\text { practice }\end{array}$ & $\begin{array}{l}\text { *PBZ solution } \\
\quad(\mathrm{ppm})\end{array}$ & & & \\
\hline \multirow{4}{*}{ Non-pinching } & 0 & $4.34 \pm 0.10$ & $4.63 \pm 0.13$ & $2.64 \pm 0.11$ \\
\hline & 15 & $3.74 \pm 0.14$ & $4.69 \pm 0.09$ & $2.31 \pm 0.09$ \\
\hline & 30 & $2.20 \pm 0.17$ & $4.63 \pm 0.08$ & $2.38 \pm 0.08$ \\
\hline & 60 & $1.56 \pm 0.18$ & $4.31 \pm 0.13$ & $2.31 \pm 0.09$ \\
\hline \multirow{4}{*}{ Pinching } & 0 & $4.56 \pm 0.20$ & $5.00 \pm 0.16$ & $2.75 \pm 0.09$ \\
\hline & 15 & $3.11 \pm 0.13$ & $4.75 \pm 0.13$ & $2.30 \pm 0.11$ \\
\hline & 30 & $1.81 \pm 0.19$ & $4.56 \pm 0.22$ & $2.38 \pm 0.08$ \\
\hline & 60 & $1.60 \pm 0.15$ & $4.19 \pm 0.09$ & $2.31 \pm 0.09$ \\
\hline \multirow{3}{*}{$\mathrm{P}$ value } & Pinching & 0.0996 & 0.5206 & 0.7102 \\
\hline & PBZ solution & $<0.0001$ & 0.0008 & 0.0003 \\
\hline & $\begin{array}{l}\text { Pinching*PBZ } \\
\text { solution }\end{array}$ & 0.0378 & 0.2759 & 0.9016 \\
\hline
\end{tabular}

*PBZ: Paclobutrazol powder (25\% WP)

Values represent mean \pm standard error of eight replicates. 
Table V. Weights of single flower of Henckelia Royal Queen at $13^{\text {th }}$ week after treatment as influenced by pinching and Paclobutrazol powder

\begin{tabular}{|c|c|c|c|}
\hline \multicolumn{2}{|r|}{ Treatment } & \multicolumn{2}{|c|}{ Average weight of single flower } \\
\hline \multirow{2}{*}{$\begin{array}{l}\text { Pinching } \\
\text { practice }\end{array}$} & \multirow{2}{*}{$\begin{array}{l}\text { *PBZ solution } \\
\quad(\mathrm{ppm})\end{array}$} & & \\
\hline & & Fresh weight & Dry weight \\
\hline \multirow{4}{*}{ Non-pinching } & 0 & $0.21 \pm 0.00$ & $0.02 \pm 0.00$ \\
\hline & 15 & $0.31 \pm 0.00$ & $0.03 \pm 0.00$ \\
\hline & 30 & $0.29 \pm 0.00$ & $0.02 \pm 0.00$ \\
\hline & 60 & $0.25 \pm 0.00$ & $0.01 \pm 0.00$ \\
\hline \multirow{4}{*}{ Pinching } & 0 & $0.23 \pm 0.00$ & $0.02 \pm 0.00$ \\
\hline & 15 & $0.27 \pm 0.00$ & $0.02 \pm 0.00$ \\
\hline & 30 & $0.27 \pm 0.00$ & $0.02 \pm 0.00$ \\
\hline & 60 & $0.29 \pm 0.00$ & $0.02 \pm 0.00$ \\
\hline \multirow{3}{*}{$P$ value } & Pinching & 0.7534 & 0.0178 \\
\hline & PBZ solution & $<0.0001$ & 0.0976 \\
\hline & Pinching*PBZ solution & $<0.0001$ & 0.0006 \\
\hline
\end{tabular}

*PBZ: Paclobutrazol powder (25\% WP).

Values represent mean \pm standard error of eight replicates

In case of PBZ treatment, it showed significant difference $(\mathrm{P}<0.05)$ with number of flower buds per plant and when WAT (week after application of treatments) increased the significant difference also increased correspondently (Table III). The $30 \mathrm{ppm}$ treated plants were shown highest number of flower buds per plant in non-pinching plants at $13^{\text {th }}$ WAT it was obvious that highest number of buds was recorded in 15 ppm PBZ treated and pinched plants. When consider about overall effect of PBZ treatment for number of flower bud formation per plant in Henckelia Royal Queen, the 0 ppm PBZ treated plants were recorded significantly low number of flower buds per plant when compared with PBZ treated plants. As a whole, PBZ treated plants has shown higher number of flower buds (Fig. 1).

\section{Number of flowers}

All the treatments failed to exert significant effect $(\mathrm{P}>0.05)$ on number of flowers per plant as a whole (Table II) in Henckelia Royal Queen plants. At $13^{\text {th }}$ WAT, both pinched and non-pinched plants were shown increased number of flowers in PBZ treated plants when compared with PBZ 0 ppm applied plants. But Abd El-aal and Mohamed (2017) mentioned that the increase of number of flowers per plant of Pelargonium zonale L. plants is proportional with the increment of paclobutrazol concentration in the two seasons and interactions between pinching and paclobutrazol concentrations statistically increased the flowers number per plant, hence the highest number of flowers per plant was recorded by pinched plants sprayed with highest PBZ concentration due to the nature of PBZ effects on the prolongation of the vegetative and reproductive growth of Tabernaemontana coronaria Stapf plants. Since, increasing the endogenous level of cytokinin by PBZ led to increasing the formation of leaves as well as the number of branches per plant. This effect was reflected on the increase in the formation of the number of flowers per plant. Therefore, present results can be explained as due to the shortening effect of PBZ, even the number of flowers was increased in PBZ treated plants, number of flowers was remained unchanged when compared with non-PBZ treated plants.

\section{Pedicel length}

Flower pedicel lengthor flower stalk length was observed highly significant $(\mathrm{P}<0.0001)$ with $\mathrm{PBZ}$ treatment applications (Table IV). At the $13^{\text {th }} \mathrm{WAT}$, it was observed that increasing PBZ concentrations have reduced the pedicel length of the Henckelia Royal Queen plants. The maximum 
pedicel length was recorded in PBZ non-treated (0 ppm) plants while minimum pedicel length was observed in $60 \mathrm{ppm}$ PBZ treated plants. These obtained results were agreed with Mansuroglu et al. (2009) who stated that pedicel lengths were linearly decreased with increasing concentrations of paclobutrazol. The overall PBZ effect on Henckelia Royal Queen Flower pedicel length was shown in Fig. 2. Pinching has not shown significant difference $(\mathrm{P}=0.0996)$ with the flower pedicel length while interaction of pinching and PBZ has shown significant difference $(\mathrm{P}=0.0378)$ on pedicel length.

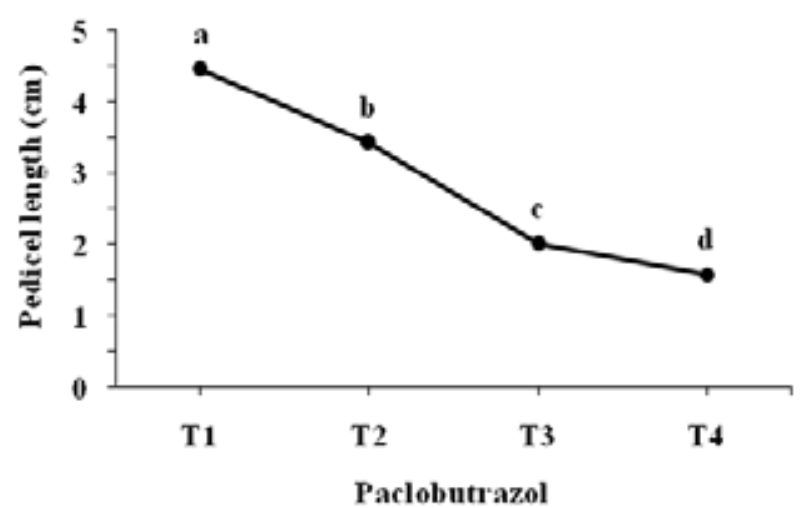

Fig. 2. Influence of pinching and Paclobutrazol powder on overall length of flower pedicel of Henckelia Royal Queen plant at $13^{\text {th }}$ week after treatment

\section{Corolla length}

Pinching and interaction effect have not shown the significant difference $(\mathrm{P}>0.05)$ on corolla length of Henckelia Royal Queen plants. But the PBZ treatment showed highly significant difference $(\mathrm{P}=0.0008)$ on flower corolla length. The data obtained at $13^{\text {th }}$ WAT was shown in Table IV. According to the data obtained, results showed the decreasing pattern with increasing concentrations of PBZ. Hence, the maximum corolla length recorded in PBZ non-treated plants while minimum corolla length in $60 \mathrm{ppm}$ PBZ treated plants. The overall effect of PBZ on corolla length (liner reduction of corolla length) has been presented in Fig. 3. These results were agreed with Mansuroglu et al. (2009) on Consolida orientalis.

\section{Corolla width}

The recorded data on corolla width is shown in Table IV. Present results revealed that there was no significant effect ( $\mathrm{P}=0.7102)$ of pinching on flower width of Henckelia
Royal Queen plants. The interaction effect between pinching and PBZ concentrations was found nonsignificant $(\mathrm{P}=0.9016)$ in influencing corolla width. Even though, PBZ showed highly significant difference $(\mathrm{P}=0.0003)$ with the corolla width of the Henckelia Royal Queen plants. The data shows reduction of corolla width with the increasing concentration of PBZ when maximum corolla width was recorded in PBZ non-treated plants. The gradual descending of corolla width can be explained by reduction of cell elongation with the increasing concentrations of PBZ. But, previous studies on corolla width of Consolida orientalis by Mansuroglu et al. (2009) stated that corolla width was not influenced by PBZ. In the present study, the overall PBZ effect on corolla width is given in Fig. 4.

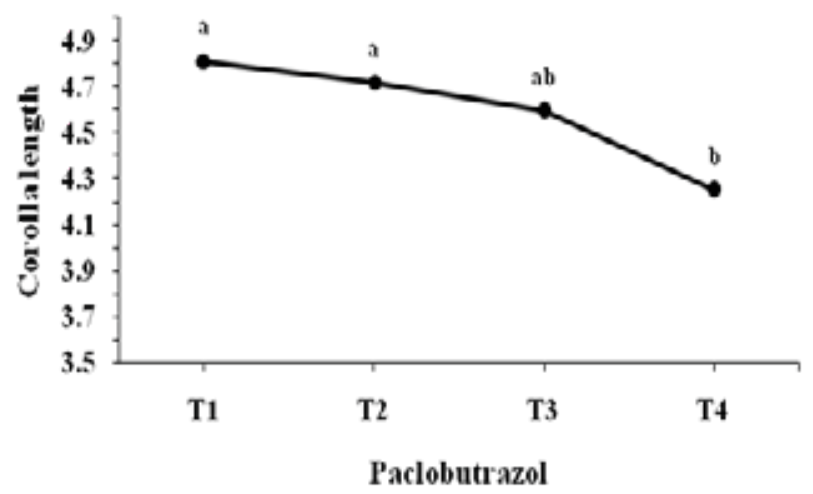

Fig. 3. Influence of pinching and Paclobutrazol powder on overall length of corolla of Henckelia Royal Queen plant at $13^{\text {th }}$ week after treatment

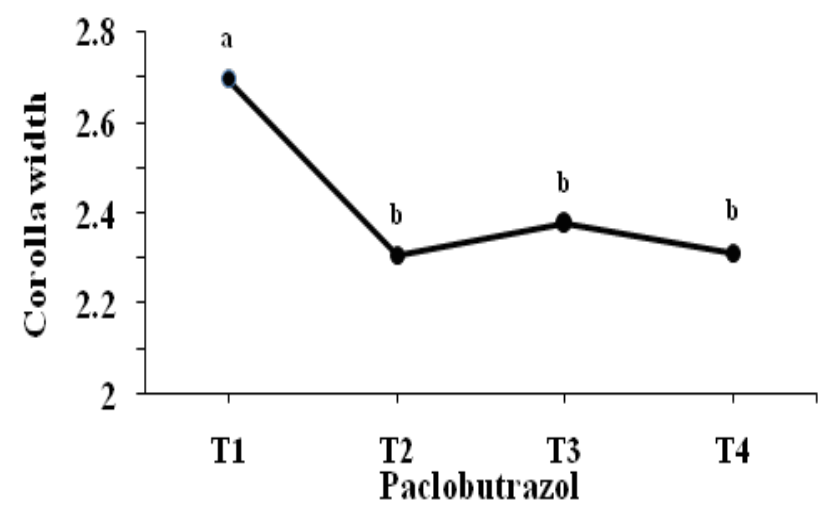

Fig. 4. Influence of pinching and Paclobutrazol powder on overall width of corolla of Henckelia Royal Queen plant at $13^{\text {th }}$ week after treatment 


\section{Fresh weight of single flower}

Fresh weight of single flower of Henckelia Royal Queen plant at $13^{\text {th }}$ WAT is given in Table V. There was no significant $(\mathrm{P}=0.7534)$ effect of pinching on fresh weight of flower. But application of PBZ solution and interaction effect showed that there was significant $(\mathrm{P}<0.0001)$ effect on fresh weight of flower. Fresh weight of flowers was increased in PBZ treated plants as compared with non-treated plants. Lowest flower weight was recorded in 0 ppm PBZ treated plants at $13^{\text {th }}$ WAT while highest flower weight was reported in $60 \mathrm{ppm}$ PBZ treated plants with pinching. The obtained result of the fresh weight of flowers was coincided with Abd El-aal and Mohamed (2017) on potted Geranium (Pelargonium zonal).

\section{Dry weight of single flower}

The analyzed results obtained from dry weight data showed significant difference $(\mathrm{P}=0.0178)$ with pinching (Table V). In case of dry weight of the flowers, PBZ application has not shown any significance difference $(\mathrm{P}=0.0976)$ on Henckelia Royal Queen plants. Hence, the present result disagreed with Sharaf-Eldien et al. (2017) in Zinnia elegans and Abd El-aal and Mohamed (2017) in Pelargonium zonal about the effect of PBZ on dry weight of the flowers on Henckelia Royal Queen plants. But, due to the analyzed data, plants showed that there was remarkable difference $(\mathrm{P}=0.0006)$ due to interaction of pinching and PBZ on dry weight of Henckelia Royal Queen plants.

\section{Conclusion}

The experiment was carried out to study the effect of pinching practice and different concentrations of Paclobutrazol (PBZ) as a soil drench application on flowering of Henckelia Royal Queen plants. It was obvious from the aforementioned results that pinching reduced dry weight of the single flower, while failed to exert any effect on fresh weight of single flower. Most importantly, pinching did not have any effect on any of the flowering parameters measured during the experiment. It was clear from the results of the experiment that increasing concentrations of PBZ (0-60 ppm) obviously decreased fresh weight of single flower, number of flower buds per plant, pedicel length, corolla length and corolla width while did not exert any effect on dry weigh of single flower, days taken to flowering and number of flowers per plant. Hence, the experiment has revealed pinching and application of PBZ has the interaction effect or the direct influence on fresh and dry weight of single flower, number of days taken to flowering, number of flower buds per plant and on pedicel length. It was obvious that, with the increasing concentration of PBZ, length of flowering elements has been reduced and was given smaller flowers that compatible with dwarf Henckelia Royal Queen plants.But the increasing concentration of PBZ, simultaneously increased the deformity of leaves. Therefore, 15 ppm PBZ application with pinching practice could be recommended to obtain dwarf Henckelia Royal Queen plants with better flowering elements as commercial potted plants.

\section{References}

Abd El-aal MMM and Mohamed YFY (2017), Effect of Pinching and Paclobutrazol on Growth, Flowering, Anatomy and Chemical Compositions of Potted Geranium (Pelargonium zonal L.) Plant, International Journal of Plant and Soil Science 17(6): 1-22. DOI: 10.9734/IJPSS/2017/34527.

Brum B, Santos VJ, Rodrigues MA, Belle RA and Lopes SJ (2007), Growth, duration of the growing stages and inflorescence production of chrysanthemum under different prunings and size of pot, Ciencia Rural 37(3): 682-689. DOI: 10.1590/S0103-84782 007000300013.

El-Bably SZ (2008), Growth and flowering of Anisacanthus wrightii plant as affected by cycocel and paclobutrazol application, Alexandia Journal of Agricultural Research 53(1): 73-80, DOI: 10.13140/RG.2.2.22 292.40320 .

Hematharshini A and Seran TH (2019), Effect of leaf segments and potting media on plant performance of Sansevieria trifasciata Hort. ex Prain grown under ex vitro conditions, Turkish Journal of Agriculture-Food Science and Technology 7(11): 1743-1747. DOI: org/10. 24925/turjaf. v7i11.1743-1747.2394

Jindal M Thumar BV and Hallur V (2018), Effect of planting time and pinching on flowering and flower quality of Chrysanthemum CV. Ratlam Selection, Journal of Pharmacognosy and Phytochemistry 7(4): 390-393.

Mansuroglu SIBEL, Karaguzel O, Ortacesme V and Sayan MS (2009), Effect of paclobutrazol on flowering leaf and flower colour of consolida orientalis, Pakistan Journal of Botany 41(5): 2323-2332. 
Nain S, Beniwal BS, Dalal RPS and Sheron S (2017), Effect of pinching and spacing on growth, flowering and yield of African marigold (Tagetes erecta L.) under semi - arid conditions of Haryana, Journal of Applied and Natural Science, 9(4): 2073-2078. DOI: 10.31018/jans. v9i4.1491.

Ona AF, Taufique T, Roni MZK, Jui NJ and Jamal-Uddin AFM (2015), Influence of pinching on growth and yield of snowball Chrysanthemum, International Journal of Business, Social and Scientific Researches 3(3): 174-178.

Pinto ACR, Graziano TT, Barbosa JC and Lasmar FB (2006), Growth retardants on production of flowering potted Thai tulip, Bragantia 65: 369-380. DOI: 10.1590/ S0006-87052006000300002

Rady MM and Gaballah MS (2012), Improving barley yield grown under water stress conditions, Research journal of Recent Sciences 1(6): 1-6.

Rathfon MR (2005), Growth retardants: A promising tool for managing urban trees, Purdue Extension document, FNR-252-W. Retrieved from: http://www.extension. purdue.edu/extmedia/FNR/FNR-252-W.pdf.

Seran TH and Krishanthy A (2009), Impact of removal of shoot tips on productivity of greengram (Vigna radiata L.). The Asian and Australasian Journal of Plant Science and Biotechnology 3(1): 51-54.

Shahin SM, Manoly ND, Ahmed SS and Samira (2006), Production of stunted Rudbeckia, Minufiya Journal of Agricultural Researches 31(1): 89-106.

Sharaf-Eldien MN, El-Bably SZ and Magouz MR (2017), Effect of Pinching and Spraying of Paclobutrazol on Vegetative Growth, Flowering and Chemical Composition of Zinnia elegans Jacq, Journal of Plant Production, 8(5): 587-592. DOI: 10.21 608/jpp.2017.40474.
Singh AK, Singh SV, Sisodia A and Asmita RH (2015), Effect of Pinching and Nitrogen on Growth, Flowering and Seed Yield in African Marigold cv, Pusa Narangi Gainda, Environment and Ecology, 33(4B): 1876-1879.

Singh R, Meena ML, Verma S, Mauriya SK, Yadav S, Kumar V, Singh V, Kumar L and Maurya SK (2019), A Review on Effect of Pinching on Growth, Flowering and Flower Yield of Marigold, Indian Journal of Pure Applied Bioscience, 7(4), 493-501. DOI: 10.18782/2320-7051.7760.

Weber A (2004), Gesneriaceae, In Flowering plants. Dicotyledons, Springer, Berlin, Heidelberg, pp 63-158.

Weber A, Middleton DJ, Forrest A, Kiew R, Lim CL, Rafidah AR, Sontag S, Triboun P, Wei YG, Yao TL, and Möller M (2011), Molecular systematics and remodelling of Chirita and associated genera (Gesneriaceae), Taxon 60(3): 767-790, DOI: 10.1002/tax.603012.

Wei S and Han B (1997), Studies on production of desk chrysanthemum by applying B9 as dwarfing agent, Journal of China Agricultural University 2(3): 101-105.

Yewale AK, Belorkar PV, Chanekar MA, Bhattacharya J and Chimukar BS (1998), Effect of growth-retadant paclobutrazol on growth parameters of Chrysanthemum, Journal of soil and crops 8(1): 82-84.

Zhu LH, van de Pepple A, Li XY and Welander M (2004), Changes of leaf water potential and endogenous cytokinins in young apple trees treated with or without paclobutrazol under drought conditions, Scientia Horticulturae, 99(2): 133-141, DOI: 10.1016/ S03044238(03)00089-X. 